\title{
THE AMINO TERMINAL SEQUENCE OF SUPEROXIDE DISMUTASE FROM SACCHAROMYCES CEREVISIAE
}

\author{
by \\ CARSTEN PETERSEN, VILLY HASEMANN, \\ BRIAN MARTIN, JACK T. JOHANSEN, \\ IB SVENDSEN and MARTIN OTTESEN \\ Department of Chemistry, Carlsberg Laboratory \\ Gamle Carlsberg Vej 10, DK-2500 Copenhagen, Valby
}

Keywords: Superoxide dismutase, Saccharomyces cerevisiae, amino-terminal sequence

The amino-terminal amino acid sequence of fifty-four residues was determined for the $\mathrm{Cu}, \mathrm{Zn}$-superoxide dismutase isolated from Saccharomyces cerevisiae. The sequence shows a high degree of homology to that of the $\mathrm{Cu}, \mathrm{Zn}$-enzyme isolated from bovine erythrocytes, but the enzyme appears to be distinctly different from the family of Mn or Fe superoxide dismutases.

\section{INTRODUCTION}

Superoxide dismutases are metalloenzymes catalyzing the dismutation of the superoxide radical to oxygen and hydrogen peroxide $(4,5$, 10). The major function of these enzymes is generally believed to be the removal of the toxic superoxide radical from biological systems, where this radical is formed as a byproduct in metabolically important redox processes. Consistent with this function, the superoxide dismutases are widely distributed in nature $(4,5,10)$.
The superoxide dismutases can be divided according to their metal contents into two classes $(4,15)$. The first class of enzymes which contain either $\mathrm{Mn}$ or $\mathrm{Fe}$ as integral parts of their active sites have similar amino acid composition and exhibit a very high degree of homology in their amino-terminal sequences (2, $14,15)$. These enzymes are found as dimers in prokaryotes and as tetramers in eukaryotic mitochondria $(4,5,10)$. They consist of identical subunits having molecular weights close to 20,000 and contain one metal atom per subunit. 
The second class of dismutases which are found in the cytoplasma of eukaryotes contain one $\mathrm{Cu}$ and one $\mathrm{Zn}$ atom per subunit. These enzymes have been shown to have similar physico-chemical properties, and are composed of two identical subunits with molecular weights of about $16,000(4,5)$. The $X$-ray structure and the complete amino acid sequence has been reported for the bovine erythrocyte superoxide dismutase $(12,13,16)$. A comparison of the amino-terminal sequence of this enzyme with that of the $\mathrm{Mn}$ and Fe class of superoxide dismutases revealed no significant homology between the two classes (15).

The present report describes the determination of the sequence of the 54 amino terminal residues by automated Edman degradation of the $\mathrm{Cu}, \mathrm{Zn}$-superoxide dismutase isolated from S. cerevisiae. Comparison of this sequence with the sequence of the superoxide dismutase from bovine erythrocytes shows a high degree of homology and indicates that these two enzymes belong to the same class of homologous superoxide dismutases.

\section{MATERIALS AND METHODS}

\subsection{Materials}

S. cerevisiae was obtained as bakers' yeast from De Danske Spritfabrikker. Microgranular DEAE-cellulose, DE-52, was from Whatman Biochemicals Ltd., Maidstone, England. Sephadex G-25 was a product of Pharmacia, Fine Chemicals, Uppsala, Sweden. Ultradex gel and Ampholines for isoelectric focusing were purchased from LKB-Produkter AB, Bromma, Sweden.

For sequence determinations the following chemicals were employed. $N: N: N^{1}: N^{1}$-tetrakis (2-hydroxyethyl) ethylene diamine (THEED)* was obtained from ICN-K\&K Laboratories Inc., Plainview, New York, and used without further purification. Ethyl acetate (UV solvent grade) was purchased from Merck Chemicals, West Germany. Both THEED and ethyl acetate were found to be free of aldehydes as determined by the Tollens' reaction (3). Phenylisothiocyanate, heptane, heptafluorobutyric acid, 1-propanol, trifluoroacetic acid, benzene and $1 \mathrm{M}$-Quadrol were all Sequanal grade reagents from Pierce Chemicals, Rockford, Ill., U. S. A. Butyl chloride was a product of Beckman Instruments, Palo Alto, Calif. The $0.5 \mathrm{M}$-THEED used as the coupling buffer in place of $1 \mathrm{M}$-Quadrol and the ethyl acetate containing 15\% 1-propanol were prepared according to the procedure described by BEGG and MORGAN (7).

\subsection{Preparation of yeast superoxide dismutase}

The $\mathrm{Cu}, \mathrm{Zn}$-superoxide dismutase from bakers' yeast was isolated essentially as described by GoSCIN and FRIDOVICH (6) with the modification that $100 \mathrm{ml} 0.1 \mathrm{M}-\mathrm{Na}_{2} \mathrm{CO}_{3}$ and $60 \mathrm{ml}$ ethanol-chloroform mixture (volume ratio 5:2) was added per $100 \mathrm{~g}$ of yeast. Analytical isoelectric focusing of the pooled, activity containing fractions from the DE-52 chromatography demonstrated several protein bands, and consequently preparative isoelectric focusing was used as the next purification step. The LKB 2117 Multiphor was used with Ultradex gel and Ampholines giving a gradient from $\mathrm{pH} 4$ to $\mathrm{pH} 6(8)$. The protein band containing the superoxide dismutase activity could be identified in the gel by visual inspection due to its blue-green colour. After elution of the active band from the gel, the enzyme was desalted and separated from the Ampholines by Sephadex G-25 gel filtration. The enzyme was stored as a lyophilized material. Only a single protein band was observed by analytical isoelectric focusing of this product.

\subsection{Amino acid analysis}

Duplicate samples for amino acid analysis were hydrolyzed in vacuo for $24,48,72$ and $96 \mathrm{~h}$ at $110^{\circ} \mathrm{C}$. The analyses were carried out with a Durrum D-500 Amino Acid Analyzer. Half-cystine and methionine were determined as cysteic acid and methionine sulfone, respectively, after performic acid oxidation as described by HIRS (7). 


\subsection{Amino terminal sequence determination}

Automated Edman degradation was performed on two protein samples using a Beckman $890 \mathrm{C}$ sequencer and the Beckman program no, 122974 (single cleavage, protein, Quadrol). In the second experiment the procedure was modified by replacing I $\mathrm{M}$ Quadrol $\left(\mathrm{R}_{2}\right)$ by $0.5 \mathrm{M}$-THEED and adding $15 \%$ propanol to the ethyl acetate $\left(\mathrm{S}_{2}\right)$ as suggested by BEGG and MORGAN (1) to improve repetitive yields. These were calculated to be $95 \%$ in the first experiment and $98 \%$ in the second experiment based on the molar ratios of alanines in positions 4 and 23 .

Thin layer chromatography on $7.5 \times 7.5 \mathrm{~cm}$ polyamide sheets, as described by KULBE (9), was used for preliminary identification of the PTH-derivatives of the amino acid residues. Further verification and quantitation was performed by back-hydrolysis for 4 hours using $5.7 \mathrm{M}-\mathrm{HCl}$ containing $0.1 \% \mathrm{SnCl}_{2}$ at $150^{\circ} \mathrm{C}$ (11) and by high performance liquid chromatography (HPLC) using a Hewlett-Packard 1084A chromatograph equipped with a RP-8, $10 \mu$, reverse phase column. A gradient elution program was used employing $0.01 \mathrm{M}$-sodium acetate $\mathrm{pH} 4.08$, containing $10 \%$ acetonitrile as initial eluant and pure acetonitrile as second eluant. This procedure was especially useful for identification of PTH-serine and PTHthreonine, which were difficult with either TLC or back hydrolysis, and for identification of PTH-asparagine and PTH-glutamine.

\section{RESULTS AND DISCUSSION}

Preparative isoelectric focusing in Ultradex gels was found to be a convenient method for isolation of superoxide dismutase in large quantities. The amino acid composition (Table I) was in reasonable agreement with the composition previously published by GosCIN and

Table I.

Amino acid composition of yeast superoxide dismutase

\begin{tabular}{l|c|c}
\hline & $\begin{array}{c}\text { Experimental values } \\
\text { Residues per mole of } \\
\text { enzyme }\end{array}$ & $\begin{array}{c}\text { Goscin and Fridovich (6) } \\
\text { Residues per mole of } \\
\text { enzyme }\end{array}$ \\
\hline Amino acid & 29.6 & 32 \\
Threonine & $16.8^{\text {a) }}$ & 18 \\
Serine & $18.4^{\text {a) }}$ & 20 \\
Glutamic acid & 23.5 & 25 \\
Proline & 12.8 & 20 \\
Glycine & 37.8 & 40 \\
Alanine & 22.7 & 24 \\
Valine & $29.1^{\text {b) }}$ & 28 \\
Methionine & $1.6^{c}$ & 2 \\
Isoleucine & $9.8^{\mathrm{b})}$ & 9 \\
Leucine & 11.0 & 11 \\
Tyrosine & 1.9 & 2 \\
Phenylalanine & $10.2^{\mathrm{b})}$ & 10 \\
Histidine & 10.3 & 11 \\
Lysine & 17.4 & 18 \\
Arginine & 6.5 & 7 \\
Half-cystine & $3.5^{\mathrm{d})}$ & 4 \\
Tryptophan & 0 e) & 0 \\
\hline
\end{tabular}
a) extrapolated to zero time
b) value after 96 hours of hydrolysis
c) determined as methionine sulfone after performic acid oxidation
d) determined as cysteic acid after performic acid oxidation
e) determined spectrophotometrically by the method of Goodwin and Morton,
(Biochemical Journal 40, 628-632 (1946)). 
Table II

The comparison of the amino terminal sequence of the $\mathrm{Cu}, \mathrm{Zn}$-superoxide dismutases from bovine erythrocyte and Saccharomyces cerevisiae. Identical residues are enclosed in boxes and residues interconvertible by a one base change per DNA codon are underlined.

\begin{tabular}{|c|c|}
\hline & 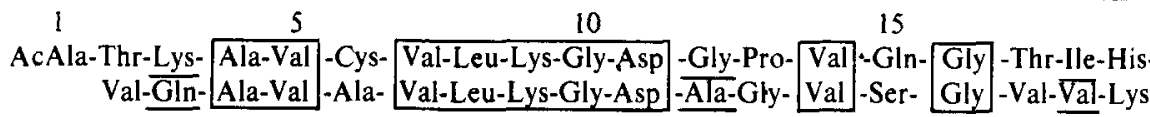 \\
\hline & 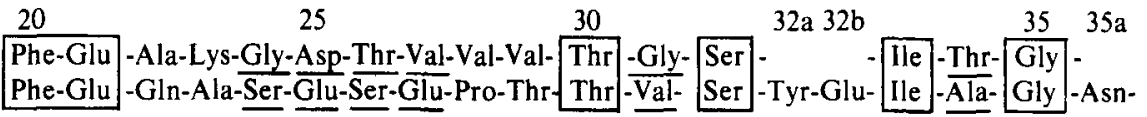 \\
\hline & 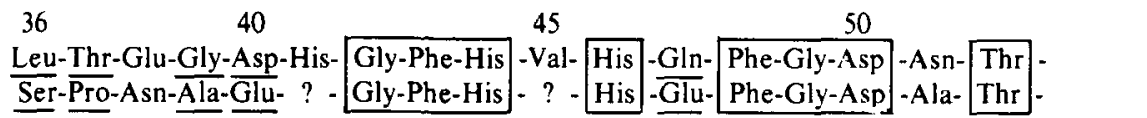 \\
\hline
\end{tabular}

FRIDOVICH (6), except for proline residues, where we found a considerably lower value.

In contrast to the bovine erythrocyte enzyme, the yeast enzyme was found to have a free a-amino group on the amino terminal residue allowing sequence analysis of the native yeast superoxide dismutase. Two sequence analyses on protein samples of $0.2 \mu \mathrm{mol}$ and 0.4 $\mu \mathrm{mol}$, respectively, were performed. The first, using Quadrol as the coupling buffer, provided the sequence of the first 30 amino acids while the second, employing THEED as the coupling buffer, identified the sequence of 52 of the first 54 amino acids as reported in Table II. Comparison of the amino terminal sequences of the yeast and the bovine $\mathrm{Cu}, \mathrm{Zn}$-superoxide dismutases shows a high degree of sequence homology. Alignment of the residues for maximum homology (23 of 54 amino acid positions) required that the sequence of the yeast enzyme started at position 2 of the bovine enzyme sequence. Thus the yeast enzyme is not only lacking the acetyl group on the $\alpha$-amino group, but it is also lacking the first residue of the bovine enzyme. In addition, insertion of three amino acid residues in the region from residues 32 to 36 was also necessary to obtain maximal homology with the bovine enzyme.

The residues in the yeast dismutase up to and including position 32 show identical amino acids in 13 places and 8 of the non-identical residues are interconvertible by a minimum of one base change per DNA codon. The next area of homology involves residues from position 32 up to and including position 38 and shows 2 identical residues and 3 non-identical residues convertible by a one base change. $X$ ray structural analysis of the bovine dismutase (13) shows that the residues 33,34 and 35 are involved in a segment of $\beta$-pleated sheet while the two residues 36 and 37 are located in a loop connecting another $\beta$-pleated sheet beginning with position 38. If the three-dimensional structure of the yeast enzyme is similar to that of the bovine enzyme, the insertion of 3 amino acid residues in this region in the yeast dismutase would appear to be easily accomodated in the structure without disrupting the conformation to any great extent.

The third area of sequence homology is that encompassing the two histidine residues 44 and 46 , involved in $\mathrm{Cu}$-binding in the bovine dismutase (13). In this region 8 out of 14 residues are identical and an additional 3 residues are interconvertible by a one base change per DNA codon. Since the two histidine residues 44 and 46 are also found in the yeast enzyme, it is indicated that the active site is similar to that of the bovine dismutase.

In summary, yeast superoxide dismutase shows $42 \%$ homology of the first 54 residues of the amino terminal sequence when compared with the bovine enzyme. Out of the nonidentical residues, 14 are interconvertible by a one base change per DNA codon, providing an additional $26 \%$ of relatively close relationship. 
The high degree of homology for the two $\mathrm{Cu}, \mathrm{Zn}$-superoxide dismutases is comparable to that of $\mathrm{Mn}$ and $\mathrm{Fe}$ superoxide dismutases (15). However, there is no apparent sequence homology between these two classes of enzymes (15). Thus a high degree of sequence homology seems to have been conserved throughout evolution for both the $\mathrm{Mn}$ and $\mathrm{Fe}$ and the $\mathrm{Cu}, \mathrm{Zn}$ classes of superoxide dismutases, respectively, but apparently the enzymes within these two classes have not evolved from a common ancestor.

\section{ACKNOWLEDGEMENT}

V. HASEMANN would like to thank the Carlsberg Foundation and B. MARTIN and C. PETERSEN the Board of the Carlsberg Laboratory for financial support. Special thanks to LONE SøRENSEN for excellent technical assistance with identification of PTH amino acids and to BODILCORNELIUSSEN for amino acid analyses.

\section{REFERENCES}

1. BegG, G. S. \& F. J. Morgan: A non-volatile buffer with improved performance in automated protein sequencing. FEBS Letters. 66, 243-245 (1976)

2. Bruschi, M., E. C. Hatchikian, J. Bonicel, G. Bovier-LAPIERrE \& P. COUChOUd: The Nterminal sequence of superoxide dismutase from the strict anaerobe Desulfovibrio desulfuricans. FEBS Letters. 76, 121-124 (1977)

3. Edman, P. \& A. Henschen: Sequence determination. In: Protein sequence determination, 2 nd.ed S. B. NeEdleman ed. Springer-Verlag, Berlin. pp. $262(1975)$

4. Fridovich, I.: Superoxide dismutases. Ann. Rev. Biochem. 44, 147-159(1975)

5. Fridovich, I.: Superoxide dismutases. In:
Advances in Enzymology, Alton Meister, ed., John Wiley \& Sons. Vol. 41, 35 - 97 (1974)

6. Goscin, S. A. \& I. Fridovich: The purification and properties of superoxide dismutase from Saccharomyces cerevisiae. Biochim. Biophys. Acta. 289, 276-283 (1972)

7. HiRs, C. H. W:: Determination of cystine as cysteic acid. Methods. Enzymol. 11, 59-62 (1967)

8. Karlsson, D., H. Davies, J. Öman \& U.-B. ANDERSON: LKB 2117-Multiphor-I. Analytical thin layer gel electrofocusing in polyacrylamide gel. LKB application Note (1973)

9. Kulbe, K. D.: Micropolyamide thin-layer chromatography of phenylthiohydantoin amino acids (PTH) at subnanomolar level. A rapid microtechnique for simultaneous multisample identification after automated Edman degradations. Analytical Biochemistry. 59, 564 573 (1974)

10. Malmstrøm, B. G., L.-E. Andréasson \& B. RAINHAMMAR: Copper-containing oxidases and superoxide dismutase. In: The Enzymes, 3rd ed. Paul D. Boyer ed. Academic Press. Vol XII pp. 507-579 (1975)

11. MendeZ, E. \& C. Y. LAI: Regeneration of amino acids from thiazolinones formed in the Edman degradation. Analytical Biochemistry. 68, 47-53 (1975)

12. Richardson, J. S., K. A. Thomas \& D. C RICHARDSON: Alpha-carbon coordinates for bovine $\mathrm{Cu}, \mathrm{Zn}$ superoxide dismutase. Biochem. Biophys. Res. Comm. 63, 986-992 (1975)

13. Richardson, J. S., K. A. Thomas, B. H. Rubin \& D. C. RICHARDSON: Crystal structure of bovine $\mathrm{Cu}, \mathrm{Zn}$ superoxide dismutase at $3 \dot{A}$ resolution: Chain tracing and metal ligands. Proc. Nat. Acad. Sci. USA. 72, 1349-1353(1975)

14. Sato, S. \& J. I. Harris: Superoxide dismutase from Thermus aquaticus. Isolation and characterization of manganese and apo enzymes. Eur. J. Biochem, 373-381 (1977)

15. Steinman, H. M. \& R. L. Hill: Sequence homologies among bacterial and mitochondrial superoxide dismutases. Proc.Nat.Acad.Sci. USA. 70, 3725-3729 (1973)

16. Steinman, H. M., V. R. Naik, J. L. Abernethy \& R. L. HILL: Bovine erythrocyte superoxide dismutase. J. Biol. Chem. 249, 7326-7338 (1974) 